\title{
DEGENERATIVE CERVICAL MYELOPATHY: A REVIEW OF CURRENT CONCEPTS
}

\author{
MIELOPATIA CERVICAL DEGENERATIVA: REVISÃO DOS CONCEITOS ATUAIS \\ MIELOPATÍA CERVICAL DEGENERATIVA: REVISIÓN DE LOS CONCEPTOS ACTUALES

 \\ 1. Centro Hospitalar de Entre Douro e Vouga, Orthopaedic and Traumatology Surgery Spine Division, Santa Maria da Feira, Portugal.
}

\begin{abstract}
Herbert von Luschka, a German anatomist, was the first to describe the developmental changes in the anatomical structures of the cervical spine. Degenerative cervical myelopathy (DCM) represents a collection of pathological entities that cause compression of the cervical spinal cord, resulting in a clinical syndrome typified by spasticity, hyperreflexia, pathologic reflexes, finger/hand clumsiness, gait disturbance and sphincter dysfunction. In the cervical spine, certain patients are more likely to have myelopathy due to a congenitally narrowed cervical spine canal. Degenerative changes are more common at C5 and C6 or C6 and C7 due to the increased motion at these levels. Additional contributors to canal narrowing are infolding of the ligamentum flavum, olisthesis, osteophytes, and facet hypertrophy. Myelopathy will develop in approximately $100 \%$ of patients with canal stenosis greater than 60\% (less than $6 \mathrm{~mm}$ sagittal disc cord space). Classically it has an insidious onset, progressing in a stepwise manner with functional decline. Without treatment, patients may progress toward significant paralysis and loss of function. Treatment requires surgery with either anterior or posterior decompression of the area of narrowing, and probable fusion. Factors of a poor prognosis include symptoms lasting for more than 18 months, increased range of motion in the cervical spine, and female gender. In this study, we give an overview of the state-of-the-art in DCM, with a focus on the pathophysiology, clinical presentation, differential diagnosis, imaging evaluation, natural history, treatment options and complications. Level of evidence III; Review article.
\end{abstract}

Keywords: Spinal Cord Compression; Spondylosis; Spine.

\section{RESUMO}

Herbert von Luschka, anatomista alemão, foi o primeiro a descrever as mudanças no desenvolvimento das estruturas anatômicas da coluna cervical. A mielopatia cervical degenerativa (MCD) representa um conjunto de entidades patológicas que causam compressão da medula espinhal cervical, resultando em uma síndrome clínica caracterizada por espasticidade, hiperreflexia, reflexos patológicos, perda de destreza manual, distúrbios de marcha e disfunção de esfíncteres. Certos pacientes têm maior probabilidade de desenvolver mielopatia na coluna cervical em decorrência de estenose congênita do canal cervical. As alterações degenerativas são mais comuns em C5 e C6 ou C6 e C7 devido ao aumento da mobilidade nesses níveis. Outros fatores que contribuem para a estenose do canal medular são hipertrofia do ligamento amarelo, listese, osteofitose e hipertrofia de facetas. A mielopatia cervical ocorre em aproximadamente 100\% dos pacientes com estenose do canal superior a $60 \%$, isto é, espaço da medula discal sagital menor que $6 \mathrm{~mm}$. Em geral, tem início insidioso, progredindo gradualmente com declínio funcional. Sem tratamento, os pacientes podem progredir para paralisia significativa e perda de função. O tratamento requer cirurgia de descompressão anterior ou posterior da área estenosada e provável fusão. Os fatores de mau prognóstico prevalecem no sexo feminino e incluem sintomatologia com duração superior a 18 meses e aumento da amplitude de movimento da coluna cervical. Neste estudo, apresentamos uma visão geral do estado da arte em MCD, com ênfase de fisiopatologia, apresentação clínica, diagnóstico diferencial, avaliação por imagem, história natural, opções de tratamento e complicações. Nível de evidência III; Artigo de revisão.

Descritores: Compressão da Medula Espinhal; Espondilose; Coluna Vertebral.

\section{RESUMEN}

Herbert von Luschka, anatomista alemán, fue el primero en describir los cambios en el desarrollo de las estructuras anatómicas de la columna cervical. La mielopatía cervical degenerativa (MCD) representa un conjunto de entidades patológicas que causan compresión de la médula espinal cervical, resultando en un síndrome clínico caracterizado por espasticidad, hiperreflexia, reflejos patológicos, pérdida de destreza manual, disturbios de marcha y disfunción de esfínteres. Ciertos pacientes tienen mayor probabilidad de desarrollar mielopatía en la columna cervical como consecuencia de estenosis congénita del canal cervical. Las alteraciones degenerativas son más comunes en C5 y C6 o C6 y C7, debido al aumento de la movilidad en esos niveles. Otros factores que contribuyen para la estenosis del canal medular son la hipertrofia del ligamento amarillo, listesis, osteofitosis e hipertrofia de facetas. La mielopatía cervical ocurre en aproximadamente $100 \%$ de los pacientes con estenosis del canal superior a $60 \%$, esto es, espacio de la médula discal sagital menor que $6 \mathrm{~mm}$ ). En general, tiene inicio insidioso, progresando gradualmente con disminución 
funcional. Sin tratamiento, los pacientes pueden progresar para parálisis significativa y pérdida de función. El tratamiento requiere cirugía de descompresión anterior o posterior del área estenosada y probable fusión. Los factores de mal pronóstico prevalecen en el sexo femenino e incluyen sintomatología con duración superior a 18 meses y aumento de la amplitud de movimiento de la columna cervical. En este estudio, presentamos una visión general del estado del arte en MCD, con énfasis de fisiopatología, presentación clínica, diagnóstico diferencial, evaluación por imagen, historia natural, opciones de tratamiento y complicaciones. Nivel de evidencia III; Artículo de revisión.

Descriptores: Compresión de la Médula Espinal; Espondiloses; Columna Vertebral.

\section{INTRODUCTION}

The overall frequency of neck pain is estimated to be $34 \%$, and previous studies have shown that the frequency of complaints lasting 1 month or longer was higher in women than in men. The prevalence of chronic pain and longer pain duration increases with age..$^{1-5}$

Myelopathy is a disorder that results from severe compression of the spinal cord. It is caused by a variety of conditions, including congenital stenosis, degenerative changes, rheumatoid arthritis, and trauma. Cervical spondylotic myelopathy is the most common cause of cervical spinal cord dysfunction in individuals older than 55 years. ${ }^{3}$ This debilitating condition is called cervical spondylotic myelopathy (CSM), which reflects the fact that the myelopathy is often associated with and caused by the normal osteoarthritic changes of the axial spine. ${ }^{3,6}$

\section{Pathophysiology}

The pathophysiology of degenerative cervical myelopathy (DCM) is multifactorial and can be divided into static and dynamic factors. Static factors result from congenital stenosis or acquired stenosis secondary to spondylosis and disk degeneration. (Figure 1) Intervertebral discs lose elasticity and hydration due to the loss of proteoglycan matrix with age, which leads to a biomechanical incompetence that predisposes the disc to collapse. ${ }^{6}$ This may or may not result in herniation of the annulus, causing symptoms. The resulting cervical cord stenosis may be aggravated by ossification and hypertrophy of the posterior facet joints, uncinate processes, ligamentum flavum, and posterior longitudinal ligament (PLL) ${ }^{6,7}$ (Figure 1) Dynamic factors relate to the exacerbation of spinal cord compression seen with physiological movement, and in the context of degenerative subluxation, pathological motion of the cervical spine. Asians are at increased risk of cervical myelopathy $(1.9 \%$ to $4.3 \%$ of individuals older than 30 years) due to increased prevalence of ossification of the PLL.

When considering injury to the spinal cord itself, there is histopathological evidence to suggest that there is a reduction in blood supply leading to considerable ischemia within the spinal cord, as well as physical compression. ${ }^{8}$ Pathological features of DCM include gray and white matter degeneration, anterior horn cell loss, cystic cavitation, and Wallerian degeneration of the posterior columns adjacent to the site of compression. In rat models, Karadimas et al., ${ }^{9,10}$ demonstrated decreased capillary density in the compressed spinal cord compared to controls, indicating disruption of the blood-spinal cord barrier (BSCB) in the context of progressive stenosis due to DCM. In addition to the above, with breakdown of the normal BSCB, a secondary cascade of neuroinflammation consisting of microglia activation and macrophage recruitment occurs at the site of mechanical compression within the spinal cord. ${ }^{10}$ Recent literature has investigated the inflammatory pathways involved in DCM, in particular, the increased local expression of the CX3CR1 gene and its association with increased microglia and macrophage accumulation at the compression sites. ${ }^{11}$

\section{Clinical Evaluation}

The onset of symptoms is usually after the age of 40 , often between 50 and 70 years, but it can also occur in the elderly. It is

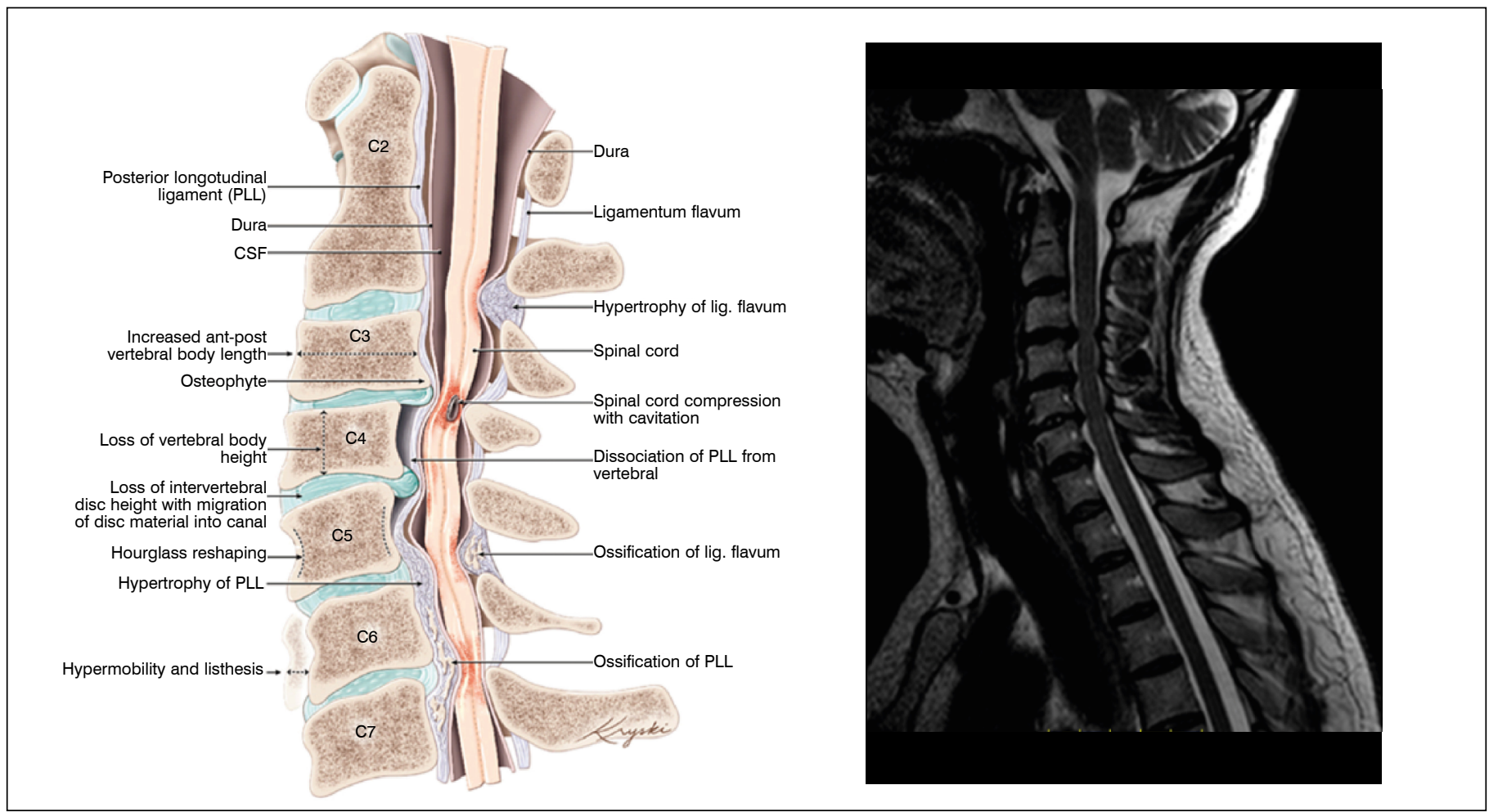

Figure 1. Pathology of DCM. (Left) Anatomy of an initially healthy spine (C2 level), with examples of the potential pathological changes that can occur and cause DCM (shown at lower spinal levels; C3-7). (Figure reproduced with permission from Diana Kryski and Michael G Fehlings). 
more prevalent in men, at a ratio of 3 to $2 .^{12}$ Typically, the onset is insidious, although symptoms can develop acutely or subacutely, often after minor head and neck trauma. A prospective study by Rhee et al., ${ }^{13}$ found that $79 \%$ of CSM patients had at least one myelopathic sign on objective physical examination, compared to $57 \%$ of healthy, normal patients.

The lateral corticospinal tracts (voluntary skeletal muscle control) and the spinocerebellar tracts (proprioception) are frequently involved in DCM. Together, these deficits are responsible for the wide-based spastic gait with clumsy upper extremity function that is classic to cervical myelopathy. ${ }^{14}$ Additional commonly involved spinal cord regions are the spinothalamic tracts, which are responsible for contralateral pain and temperature sensation, the posterior columns, which are responsible for ipsilateral position and vibration sense, and the dorsal nerve root, which is responsible for dermatomal sensation. ${ }^{15,16}$

Examination of patients with CSM typically reveals lower motor neuron signs at the level of the cervical lesions (weakness and hyporeflexia) and upper motor neuron signs below the lesions (spasticity, hyperreflexia of the deep tendons, clonus, Hoffman sign, Babinski sign and absence of fasciculation or fibrillation). Other tests such as the Spurling sign, the Lhermitte sign, crossed radial reflex, inverted radial reflex, finger escape sign and grip test should be included in the initial evaluation.

Symptoms in CSM are characteristically persistent rather than transient or fluctuating. About $75 \%$ of patients report clumsy hands and over $80 \%$ report unsteady gait and/or upper extremity sensory changes such as shock-like paresthesias with neck flexion (Lhermitte sign). ${ }^{17}$ Pain is a less frequently noted complaint and its absence may often lead to a delay in diagnosis. It has been strongly suggested that subtle gait disturbance is the most common presentation, followed by loss of fine motor control of the hands with associated numbness. Bladder and/or bowel incontinence and quadriparesis affect 15 to $50 \%$ of patients, and are usually associated with late stage myelopathy. Its development is due to long tract involvement, resulting in reduced sphincter control. ${ }^{6}$

In their study of 120 patients with cervical myelopathy, Clarke and Robinson described the natural history of this condition as following one of several patterns: $5 \%$ had rapid onset of symptoms followed by long periods of remission; $20 \%$ had a slow gradual decline in function; and $75 \%$ had a stepwise decline in function. ${ }^{18}$ Over the years, additional studies have documented a highly variable natural history.

A systematic review conducted in 2013 by Karadimas et al. ${ }^{17}$ sought to more specifically quantify the rate of clinic deterioration in patients presenting with DCM treated nonoperatively. Of the 6 studies that considered Japanese Orthopaedic Association (JOA) or modified JOA (mJOA) scores, $20 \%$ to $62 \%$ of patients experienced clinical deterioration, defined by at least a 1-point reduction in mJOA/ JOA compared to baseline, at 3 to 6 years of follow-up.

Many disease severity classifications have been used, such as the European Myelopathy Score, Nurick's Functional Scale, the Ranawat Classification of Neurological Deficit and the modified Japanese Orthopaedic Association scoring system (mJOA). A study by Kopjar et al. validated the mJOA, and marked the first step in the use of this scale as the standard for assessing severity in patients with DCM. Fehlings et al. defined mild myelopathy as a score greater than or equal to 15 , moderate myelopathy as a score from 12 to 14 , and severe disease as a score of less than $12 .{ }^{19}$

Multiple sclerosis, amyotrophic lateral sclerosis, osteomyelitis, borreliosis (Lyme disease), polyradiculitis (Landry-Guillain-Barré), vascular and neoplastic causes and psychogenic disorders should be considered in the differential diagnosis of cervical spondylosis with involvement of neural structures leading to cervical spinal myelopathy.

\section{Imaging}

Evidence of radiological degenerative changes to the cervical spine in the aging population are common. By the fourth decade of life, $30 \%$ of asymptomatic subjects show degenerative changes in the intervertebral discs, while by the seventh decade, up to $90 \%$ have developed degenerative alterations. ${ }^{20}$

Imaging techniques that assist in the diagnosis of CSM include
$\mathrm{MRI}$, flexion-extension radiography, and computed tomography (CT). Narrowing of the disc space, bone spurs, osteophytes, joint subluxation, facet joint arthrosis, spondylolisthesis, and ossification of posterior longitudinal ligament may be visualized on standard films.

Patients with a congenitally narrow canal $(<13 \mathrm{~mm})$ or with a cord compression greater than $30 \%$ are at a higher risk for developing clinical features from static mechanical compression. ${ }^{21}$ White et al., showed that cervical myelopathy should be strongly suspected when the dynamic canal space during extremes of flexion or extension is $<11 \mathrm{~mm}^{21}$. In two studies, published in 1986 and 1987, ${ }^{22,23}$ American orthopedic surgeon Joseph Torg and American radiologist Helene Pavlov introduced the ratio method for reducing inter- and intraobserver error caused by variance in magnification and landmarking. This error can be calculated by dividing the AP diameter of the spinal canal by the AP diameter of the vertebral body. A Pavlov's ratio $<0.8$ is suggestive of stenosis.

Weight-bearing films, including flexion-extension radiographs, are the definitive study for the assessment of cervical lordosis and evidence of instability that may predispose to a repetitive trauma mechanism underlying CSM. ${ }^{24} \mathrm{CT}$ scans are the best method to identify bony and calcific changes, including calcified disks, ossification of the posterior longitudinal ligament, and facet hypertrophy. CT may also demonstrate ankylosis of the uncovertebral and/or facet joints, which are important for the restoration of lordosis. Finally, noncontrast CT scan suggests the course of the vertebral arteries, potentially revealing anomalies such as tortuous vertebral artery or ponticulus posticus, which must be considered before corpectomy and placement of $\mathrm{C} 1$ screws, respectively. In the presence of an abnormally tortuous vertebral artery, using anatomic landmarks to guide decompression may not prevent iatrogenic injury to the vertebral artery. ${ }^{25,26}$

MRI demonstrates disk bulges, disk-osteophyte complexes, facet and ligamentous hypertrophy, as well as possible listhesis, all of which contribute to spinal canal stenosis and spinal cord compression. Increased T2 signal is sometimes seen in the spinal cord, suggesting spinal cord injury, including myelomalacia, from either cord compression or repetitive trauma. Patients presenting with multisegmental T2 changes on MRI often have longstanding CSM and poor neurological outcome even with decompression surgery. ${ }^{27}$

Since conventional MRI is not able to reveal the microstructural characteristics of the spinal cord, including the fiber tract of the white matter, alternative approaches, such as diffusion tensor imaging (DTI), have been developed, which may enable detailed in vivo analysis of the diffusion of water molecules. DTI is based on anisotropic diffusion parameters, and takes conventional MRI one step further by measuring differences in the amount and orientation of water diffusion, particularly in the white matter. ${ }^{28,29}$ It is a promising novel imaging modality offering increased diagnostic sensitivity as compared to standard MRI, and enabling earlier detection of CSM before T2 changes appear on conventional MRI. Once the diagnosis of CSM is established, repeated imaging is not needed unless there has been significant clinical worsening, or to aid in surgery planning.

The spectrum of neurophysiological assessment consists of electromyography (EMG), electroneurography (ENG), and evoked potentials. Electromyography (EMG) and Somatosensory Evoked Potentials (SSEPs) are diagnostic investigations that are infrequently used to exclude differential diagnoses such as multiple sclerosis, amyotrophic lateral sclerosis, and peripheral neuropathy. ${ }^{30}$

\section{Treatment}

Studies comparing conservative versus surgical treatment in mild CSM are conflicting. Some studies showed no difference between the two groups, while others showed a deterioration in patients treated conservatively. ${ }^{31}$

A Cochrane review of randomized controlled trials to investigate the role of surgery in mild CSM found only one small controlled trial. 
This trial showed no significant differences between surgical and conservative management in 68 patients after 3 years of follow-up. ${ }^{32}$

The AOSpine CSM North America Study ${ }^{33}$ remains one of the largest prospective studies conducted to evaluate the impact of surgical management on clinical outcomes. At 1-year follow-up, across the entire spectrum of injury severity, statistically and clinically significant improvements were noted for functional outcome (mJOA and Nurick grade) and disability outcome (Neck Disability Index $[\mathrm{NDI}]$ ), as well as generic health-related quality of life (SF-36). The results of that study seem to indicate that surgery is most effective in restoring function in those with moderate or severe myelopathy at presentation, but also that cervical decompression prevents further deterioration and improves neurological outcomes, functional status and quality of life (QOL).

A subsequent prospective study (AOSpine International CSM) ${ }^{34}$ confirmed some of the findings reported in the North American Study, providing external validity to its conclusions.

In another prospective study on this topic, Sampath et al. ${ }^{35}$ assessed rating of neurological symptoms, activities of daily living, pain, and ability to work, amongst two cohorts of DCM patients: one cohort treated with surgical intervention and the other with nonsurgical treatment (pharmacological therapy with either narcotic or nonsteroidal drugs, steroids, bed rest, home exercise, cervical traction, neck bracing, or spinal injections). Compared to baseline, nonsurgical patients had an increased number of neurological symptoms, worsened activities of daily living, and a more severe pain rating at 11-month follow-up. Several retrospective studies have demonstrated no benefit of rigid immobilization in the absence of surgery. ${ }^{36}$

In summary, a large body of literature has shown that surgical management of DCM has the potential to improve outcomes, and to maintain these results after a long period of follow-up.

Although it remains unclear whether patients with mild CSM benefit from surgery when compared to conservative management, patients with moderate to severe CSM or progressive neurologic deficits definitely do. The decision to proceed with surgery must consider the patient's age, baseline function, severity of symptoms, and the historical rate of progression. Nonsurgical treatment is a viable option in patients with radiographic evidence of cervical stenosis without clinical signs or symptoms of myelopathy. Non-surgical management for those with mild symptoms should include anti-inflammatories, physical therapy, ultrasound modalities, and occasionally, corticosteroid injections. If there is a deterioration in the patient's clinical condition, these short-term alternatives will not provide definitive treatment.

\section{Surgical Treatment}

Prolonged compression of the spinal cord can result in irreversible damage, and the results of operative treatment are better when there is early intervention. Surgical intervention can be considered in two anatomical areas: the upper (C0-C2) and lower (C3-C7) cervical spine, and by three general approaches: anterior, posterior, and combined anterior and posterior.

The four surgical procedures commonly performed to treat CSM are anterior cervical discectomy and fusion (ACDF), anterior cervical corpectomy and fusion (ACCF), laminectomy, and laminoplasty. The appropriate choice depends on the presence of preoperative neck pain, the level and degree of spondylotic change, sagittal alignment and stability of the spine, individual characteristics including previous surgery, and surgical expertise. Regardless of the chosen procedure, the goals of operative treatment are to decompress the spinal cord and its circulation, preserve the alignment and stability of the spine, and prevent further neural injury.

\section{Anterior approaches}

Initially described by Robinson and Smith in 1955 and Cloward in 1958, ACDF has become one of the most common surgical procedures for both CSM and cervical radiculopathy. ${ }^{37,38}$ The goals of ACDF are direct decompression of the cervical spinal cord from its ventral pathology, direct and indirect foraminal decompression, and restoration of cervical lordosis. It is considered the gold standard treatment for single-level and 2-level disease and is indicated for anterior pathology, particularly in the setting of cervical kyphosis. It provides relatively easy access to the vertebral column, and the surgical outcome is satisfactory in most cases. ${ }^{39}$ However, ACDF is relatively contraindicated in patients with stenosis primarily from a posterior origin, located behind the vertebral body rather than in the disk space, in patients with ossification of the posterior longitudinal ligament, and is less commonly performed in patients with $>3$ levels of disease.

Cervical disk arthroplasty is a relatively new surgical treatment option. A recent multicenter randomized controlled trial comparing cervical disk arthroplasty with anterior cervical decompression showed similar improvement in neurologic status at 2-year follow-up. ${ }^{40}$

In one of the largest studies to evaluate this question, Fehlings et al. ${ }^{40}$ performed a retrospective cohort study comparing 169 subjects treated anteriorly (ACDF or anterior cervical corpectomy and fusion) with 95 subjects treated posteriorly (laminectomy and fusion (86\%) or with laminoplasty). They found no differences in mJOA recovery or other outcomes, including NDI, SF-36, Nurick and complications. To collect evidence on this topic, Lawrence et al. ${ }^{41}$ performed a systematic review that summarized the findings of 8 retrospective cohort studies comparing anterior and posterior surgery for multilevel CSM. In summary, regarding the change in mJOA score from preoperatively to postoperatively, neither approach was consistently associated with superior outcomes.

In a patient with multilevel cervical spondylosis in whom an anterior approach is decided upon, the choice of optimal operative intervention remains controversial. Shamji et al. ${ }^{42}$ demonstrated similar trajectories of neurological recovery for patients managed by these various options, although sagittal correction and neck pain scores were best among the multiple discectomy cohort and worst among the corpectomy cohort. A similar incidence of perioperative complications was noted among the different procedures, namely pseudoarthrosis, dysphagia, and infection. The strong recommendations arising from this systematic review were that when minimal retrovertebral disease is present, multiple discectomy should be selected over hybrid or corpectomy procedures. On the other hand, in patients with significant retrovertebral disease, hybrid procedures should be selected.

\section{Posterior approaches}

Posterior procedures, such as laminoplasty and laminectomy, can achieve spinal cord decompression by expanding the canal in a posterior direction. ${ }^{43}$

The objective of both laminectomy with fusion and laminoplasty is to decompress the spinal cord. The primary indication for these procedures is multilevel cord compression in the absence of kyphosis.

Although multilevel laminectomy was historically the most popular posterior operation for the treatment of DCM, the relatively high rates $(15 \%-20 \%)$ of postlaminectomy kyphosis reported have led to a gradual rejection of this approach and to the nearly uniform adoption of either laminectomy with fusion or laminoplasty when considering a posterior operation. ${ }^{44}$ Laminectomy with instrumentation was also associated with loss of lordosis and increase in C2 SVA, these variables being negatively correlated with health-related outcomes. On the contrary, the anterior approach has been shown to be more associated with a superior capacity of kyphosis correction and the maintenance of postoperative lordosis than laminoplasty and laminectomy with instrumentation. ${ }^{15}$

Laminoplasty can be an advantageous option in lordotic spines in younger patients where fusion is undesirable. The two main laminoplasty techniques are the 'French Door' and the 'Open Door' techniques. One study reported that laminoplasty is not an effective treatment for axial neck pain, and that axial symptoms may worsen post-procedure. It is also contraindicated in patients with instability resulting from trauma or rheumatoid arthritis. ${ }^{45}$

\section{Combined approaches}

In complex cases, especially when there is compression from both anterior and posterior structures, both approaches may be 
used concurrently. Indications include patients with fixed kyphosis, multilevel stenosis, instability, and poor bone quality. Adding posterior stabilization may address the issue of suboptimal stability, particularly in cases where there is extensive resection. ${ }^{46,47}$

Shamji et al. ${ }^{48}$ demonstrated that patients with preoperative kyphosis exhibit less neurological recovery than those with preoperative lordosis, independently of whether alignment was corrected at the time of surgery. The kyphosis group also deteriorated more frequently, particularly when only the posterior approach was used, which supports the importance of restoring the cervical sagittal alignment.

\section{Surgical complications}

Fehlings et al. ${ }^{49}$ described an overall perioperative complication rate of $15.6 \%$ and an overall delayed complication rate of $4.4 \%$. Perioperative worsening of myelopathy occurred in $1.3 \%$ and the mortality rate was $0.33 \%$. Most of the reported complications were treatable and had no long-term impacts. The occurrence of perioperative complications has been associated with increased age, combined procedures, increased surgical time, and greater operative blood loss.

The anterior approach to the cervical spine is one of the most commonly performed spinal procedures. Fountas et al..$^{50}$ stated that the overall morbidity rate in their ACDF series was $19.3 \%$, while the mortality rate was $0.1 \%$. Similarly, Veeravagu et al. ${ }^{51}$ estimated that the overall mortality at 2 years was $0.1 \%$ in single level ACDF procedures, and $0.18 \%$ among their multilevel cases. Bilbao et al. reported a complication rate of $25 \%$ in patients undergoing cervical spondylotic corpectomies. ${ }^{52}$

Complications of anterior cervical surgery include dysphagia, recurrent laryngeal nerve palsy, vertebral artery injury, Horner syndrome, postoperative hematoma, esophageal injury, unintended dural tear, superficial wound infection, and hardware complications. ${ }^{52,53}$ Some studies have shown that recurrent laryngeal nerve $(R L N)$ palsy is underreported. ${ }^{54,55}$ Dysphonia and/or hoarseness are the most common clinical expression of unilateral vocal paralysis. Incidental durotomy is rare, with a reported incidence of $0.2-0.5 \% .^{50}$ Although rare, one of the most serious complications that has been reported in anterior cervical corpectomy is inadvertent laceration of the vertebral artery, with a reported incidence during cervical surgery of $0.3-0.5 \% .^{53}$

Cloward reported one of the first graft migrations. ${ }^{56}$ Since then, mechanical failure and/or screw migration have been described. Initial misplacement of the implant is the most common reason for mechanical fatigue and eventual failure of the implant. ${ }^{57}$

Nonunion can produce persistent neck pain and radicular symptoms. Rates of pseudarthrosis following ACDF range from $1 \%$ to $20 \%$ for single-level fusions and up to $50 \%$ for multilevel fusions. ${ }^{58}$ Rates after posterior laminectomy with fusion range from 1\% to $38 \%{ }^{59}$

C5 palsy is an established neurological complication and generally manifests as delayed-onset painful deltoid and biceps weakness, either unilateral or bilateral. ${ }^{60}$ No statistically significant differences in the rates of $\mathrm{C} 5$ palsy between anterior and posterior approaches have been reported. A retrospective review of 1001 cases by Bydon et al. ${ }^{61}$ found that in anterior surgeries, older age most strongly predicted development of C5 palsy while in posterior approaches, the strongest predictor was C4-C5 foraminotomy. The authors also reported a higher incidence of C5 palsy in corpectomies versus ACDF.

Postlaminectomy kyphosis has a significant harmful complication in adult patients undergoing a laminectomy without fusion for CSM. ${ }^{44}$ The incidence of postlaminectomy kyphosis in the setting of CSM in the adult population is approximately $20 \% .{ }^{45}$ Cumulative data suggest that kyphosis following cervical laminectomy without fusion develops more rapidly the less spondylotic and the younger the patient is.

\section{CONCLUSION}

Cervical spondylotic myelopathy is a debilitating condition commonly affecting the elderly that occurs as a result of degenerative changes, leading to cord compression.

The clinical diagnosis of myelopathy requires a detailed history and physical examination to define the syndrome. Because of the wide-ranging pathologies contributing to DCM development, the constellation of findings in any given patient may vary considerably. Neuroimaging is indicated in most instances of new onset myelopathy. Static and dynamic factors should be considered when establishing the causative features in the development of this condition.

There is scant evidence for nonoperative treatment of cervical myelopathy, and further studies are needed to establish its role between treatment modalities. At present, acknowledging the methodological limitations of existing studies, the body of evidence supports the efficacy of surgical treatment for symptomatic patients with moderate to severe DCM. Although these procedures are associated with severe potential risks, most perioperative and delayed postoperative complications from surgery are treatable and do not have any long-term impacts.

All authors declare no potential conflict of interest related to this article.

CONTRIBUTION OF THE AUTHORS: Each author made significant individual contributions to this manuscript. EMP: writing, statistical analysis, intellectual concept, preparation of the entire research project and approval of the final version of the work; AT: analysis of the data for the work, critical review of its intellectual content and approval of the final version of the work; RF: analysis of the data for the work, critical review of its intellectual content and approval of the final version of the work; PA: analysis of the data for the work, critical review of its intellectual content and approval of the final version of the work; FO: analysis of the data for the work, critical review of its intellectual content and approval of the final version of the work; AM: analysis of the data for the work, critical review of its intellectual content and approval of the final version of the work.

\section{REFERENCES}

1. Luschka H. Die Halbgelenke des menschlichen Körpers. Berlin: Reimers; 1858.

2. Tetreault L, Goldstein CL, Arnold P, Harrop J, Hilibrand A, Nouri A, et al. Degenerative cervical myelopathy: a spectrum of related disorders affecting the aging spine. Neurosurgery. 2015;77(suppl 4):S51-67.

3. Nouri A, Tetreault L, Singh A, Karadimas SK, Fehlings MG. Degenerative cervical myelopathy: epidemiology, genetics, and pathogenesis. Spine (Phila Pa 1976). 2015;40(12):E675-93

4. Nagoshi N, Tsuji O, Okada E, Fujita N, Yagi M, Tsuji T, et al. Clinical indicators of surgical outcomes after cervical single open-door laminoplasty assessed by the Japanese Orthopaedic Association Cervical Myelopathy Evaluation Questionnaire. Spinal Cord. 2019;57(8):644-51.

5. Nakajima H, Uchida K, Taguchi T, Yamashita T, Tominaga T, Tanaka M, et al. Multicenter cross-sectional study of the clinical features and types of treatment of spinal cord-related pain syndrome. J Orthop Sci. 2019;24(5):798-804.

6. Clark C, Frymoyer JW. The adult spine: Principles and practice, (2nd ed). Philadelphia, USA Lippincott-Raven publications; 1997.

7. Matsunaga S, Sakou T, Taketomi E, Komiya S. Clinical course of patients with ossifica- tion of the posterior longitudinal ligament: A minimum 10-year cohort study. J Neurosurg 2004;100(3 Suppl Spine):245-8.

8. Baptiste DC, Fehlings MG. Pathophysiology of cervical myelopathy. Spine J. 2006;6(6 Suppl):190S-7S.

9. Karadimas SK, Moon E, Fehlings M. The sodium channel/glutamate blocker riluzole is complementary to decompression in a preclinical experimental model of cervical spondylotic myelopathy: implications for translational clinical application. Spine J. 2012;12(9):S88-9

10. Karadimas SK, Laliberte AM, Tetreault L, Chung YS, Arnold P, Foltz WD, et al. Riluzole blocks perioperative ischemia-reperfusion injury and enhances postdecompression outcomes in cervical spondylotic myelopathy. Sci Transl Med. 2015;7(316):316ra194.

11. Yu WR, Karadimas S, Fehlings M. Human and animal model evidence supporting a role for Cx3cr1 in mediating the inflammatory response in cervical spondylotic myelopathy. Abstract Presented at: The 2012 Society for Neuroscience meeting in October, New Orleans; 2012.

12. Northover JR, Wild JB, Braybrooke J, Blano J. The epidemiology of cervical spondylotic myelopathy. Skeletal Radiol. 2012:41(12):1543-6.

13. Rhee JM, Heflin JA, Hamasaki T, Freedman B. Prevalence of physical signs in cervical myelopathy: a prospective, controlled study. Spine (Phila Pa 1976). 2009;34(9):890-5. 
14. Baron EM, Young WF. Cervical spondylotic myelopathy: a brief review of its pathophysiology, clinical course, and diagnosis. Neurosurgery. 2007;60(1 Suppl 1):S35-41.

15. Hitchon PW, Woodroffe RW, Noeller JA, Helland L, Hramakova N, Nourski KV. Anterior and Posterior Approaches for Cervical Myelopathy: Clinical and Radiographic Outcomes. Spine (Phila Pa 1976). 2019;44(9):615-23.

16. Grelat M, Gimenez C, Madkouri R. Cervical Cord Compression by Exostosis. J Orthop Sports Phys Ther. 2019;49(2):112.

17. Karadimas SK, Erwin WM, Ely CG, Dettori JR, Fehlings MG. Pathophysiology and natural history of cervical spondylotic myelopathy. Spine (Phila Pa 1976). 2013;38 (22 Suppl 1):S21-36

18. Clarke E, Robinson P. Cervical myelopathy: a complication of cervical spondylosis. Brain. 1956;79(3):483-510

19. Fehlings MG, Wilson JR, Kopjar B, Yoon ST, Arnold PM, Massicotte EM, et al. Efficacy and safety of surgical decompression in patients with cervical spondylotic myelopathy: results of the AOSpine North America prospective multi-center study. J Bone Joint Surg. 2013:95(18):1651-8

20. Dvorak J, Sutter M, Herdmann, J. Cervical myelopathy: clinical and neurophysiological evaluation. Eur Spine J. 2003:12(Suppl 2):S181-7.

21. White AA, Panjabi MM. Biomechanical considerations in the surgical management of cervical spondylotic myelopathy. Spine (Phila Pa 1976). 1988;13(7):856-60.

22. Torg JS, Pavlov H, Genuario SE, Sennett B, Wisneski RJ, Robie RH, et al. Neurapraxia of the cervical spinal cord with transient quadriplegia. J Bone Joint Surg Am. 1987;68(9):1354-70.

23. Pavlov H, Torg JS, Robie B, Jahre C. Cervical spinal stenosis: determination with vertebral body ratio method. Radiology. 1987:164(3):771-5

24. Vedantam A, Rajshekhar V. Does the type of T2-weighted hyperintensity influence surgical outcome in patients with cervical spondylotic myelopathy? A review. Eur Spine J. 2013;22(1):96-106.

25. Young JP, Young PH, Ackermann MJ, Anderson PA, Riew KD. The ponticulus posticus: implications for screw insertion into the first cervical lateral mass. J Bone Joint Surg Am. 2005:87(11):2495-8

26. Curylo LJ, Mason HC, Bohlman HH, Yoo JU. Tortuous course of the vertebral artery and anterior cervical decompression: a cadaveric and clinical case study. Spine (Phila Pa 1976). 2000;25(22):2860-4.

27. Rota JJF, Meschian S, Rota AF, Urbano V, Baron M. Cervical spondylotic myelopathy due to chronic compression: The role of signal intensity changes in magnetic resonance images. J Neurosurg Spine. 2007;6(1):17-22.

28. Shabani S, Kaushal M, Budde MD, Wang MC, Kurpad SN. Diffusion tensor imaging in cervical spondylotic myelopathy: a review. J Neurosurg Spine. 2020:1-8.

29. Stino MA, LoRusso SJ. Myelopathies due to structural cervical and thoracic disease. Continuum (Minneap Minn). 2018;24(2, Spinal Cord Disorders):567-83.

30. Campbell WW. Focal neuropathies. In: Campbell WW (ed). Essentials of Electrodiagnostic Medicine. Baltimore, USA: Williams \&Willkins publications; 1999. 255-78.

31. Matz PG, Anderson PA, Holly LT, Groffy MW, Heary RF, Kaiser MG, et al. The natural history of cervical spondylotic myelopathy. J Neurosurg Spine. 2009;11(2):104-11.

32. Nikolaidis I, Fouyas IP, Sandercock PA, Stathan PF. Surgery for cervical radiculopathy or myelopathy. Cochrane Database Syst Rev. 2010;20(1):CD001466.

33. Fehlings MG, Wilson JR, Kopjar B, Yoon ST, Arnold PM, Massicotte EM, et al. Efficacy and safety of surgical decompression in patients with cervical spondylotic myelopathy: results of the AOSpine North America prospective multi-center study. J Bone Joint Surg Am. 2013;95(18):1651-8.

34. Fehlings MG, Ibrahim A, Tetreault L, Albanese V, Alvarado M, Arnold $P$, et al. A global perspective on the outcomes of surgical decompression in patients with cervical spondylotic myelopathy: results from the prospective multicenter AOSpine international study on 479 patients. Spine (Phila Pa 1976). 2015;40(17):1322-8.

35. Sampath P, Bendebba M, Davis JD, Ducker TB. Outcome of patients treated for cervical myelopathy: A prospective, multicenter study with independent clinical review. Spine (Phila Pa 1976). 2000;25(6):670-6.

36. Gok B, Sciubba DM, McLoughlin GS, McGirt M, Ayhan S, Wolinsky JA, et al. Surgical treatment of cervical spondylotic myelopathy with anterior compression: a review of 67 cases. J Neurosurg Spine. 2008:9(2):152-7

37. Cloward RB. The anterior approach for removal of ruptured cervical disks. J Neurosurg 1958;15(6):602-17.

38. Cloward RB. History of the anterior cervical fusion technique. J Neurosurg. 1985;63(5):817-9.

39. Sasso RC, Anderson PA, Riew KD, Heller JG. Results of cervical arthroplasty compared with anterior discectomy and fusion: four-year clinical outcomes in a prospective, randomized controlled trial. J Bone Joint Surg Am. 2011;93(18):1684-92.
40. Fehlings MG, Barry S, Kopjar B, Yoon ST, Arnold P, Massicotte EM, et al. Anterior versus posterior surgical approaches to treat cervical spondylotic myelopathy: outcomes of the prospective multicenter AOSpine North America CSM study in 264 patients. Spine (Phila Pa 1976). 2013;38(26):2247-52.

41. Lawrence BD, Jacobs WB, Norvell DC, Hermsmeyer JT, Chapman JR, Brodke DS. Anterior versus posterior approach for treatment of cervical spondylotic myelopathy: a systematic review. Spine (Phila Pa 1976). 2013;38(22 Suppl 1):S173-82.

42. Shamji MF, Massicotte EM, Traynelis VC, Norvell DC, Hermsmeyer JT, Fehlings MG. Comparison of anterior surgical options for the treatment of multilevel cervical spondylotic myelopathy: a systematic review. Spine (Phila Pa 1976). 2013;38(22 Suppl 1):S195- 209.

43. Zhou X, Cai P, Li Y, Wang H, Xia S, Wang X. Posterior or single-stage combined anterior and posterior approach decompression for treating complex cervical spondylotic myelopathy coincident multilevel anterior and posterior compression. Clinical Spine Surgery. 2017;30(10):E1343-51.

44. Kaptain GJ, Simmons NE, Replogle RE, Pobereskin L. Incidence and outcome of kyphotic deformity following laminectomy for cervical spondylotic myelopathy. J Neurosurg. 2000;93(2 Suppl):199-204

45. Ohnari H, Sasai K, Akagi S, lida H, Takanori S, Kato I. Investigation of axial symptoms after cervical laminoplasty, using questionnaire survey. Spine J. 2006;6(3):221-7.

46. Williams KE, Paul R, Dewan Y. Functional outcome of corpectomy in cervical spondylotic myelopathy. Indian J Orthop. 2009;43(2):205-9.

47. Kim PK, Alexander JT. Indications for circumferential surgery for cervical spondylotic myelopathy. Spine J. 2006;6(6 Suppl):299S-307S.

48. Shamji MF, Mohanty C, Massicotte EM, Fehlings MG. The Association of Cervical Spine Alignment with Neurologic Recovery in a prospective cohort of patients with surgical myelopathy: analysis of a series of 124 cases. World Neurosurg. 2016;86:112-9

49. Fehlings MG, Smith JS, Kopjar B, Arnold PM, Yoon ST, Vaccaro AR, et al. Perioperative and delayed complications associated with the surgical treatment of cervical spondylotic myelopathy based on 302 patients from the AOSpine North America Cervical Spondylotic Myelopathy Study. J Neurosurg Spine. 2012;16(5):425-32

50. Fountas KN, Kapsalaki EZ, Nikolakakos LG, Smisson HF, Johnston KW, Grigorian AA, et al. Anterior cervical discectomy and fusion associated complications. Spine (Phila Pa 1976). 2007:32(21):2310-7

51. Veeravagu A, Cole T, Jiang B, Ratliff JK. Revision rates and complication incidence in singleand multilevel anterior cervical discectomy and fusion procedures: an administrative database study. Spine J. 2014;14(7):1125-31.

52. Bilbao G, Duart M, Aurrecoechea JJ, Pomposo I, Igartua A, Catalán G, et al. Surgical results and complications in a series of 71 consecutive cervical spondylotic corpectomies. Acta Neurochir (Wien). 2010;152(7):1155-63.

53. Burke JP, Gerszten PC, Welch WC. latrogenic vertebral artery injury during anterior cervical spine surgery. Spine J. 2005;5(5):508-14; discussion 14.

54. Ebraheim NA, Lu J, Yang $H$, Heck BE, Yeasting RA. Vulnerability of the sympathetic trunk during the anterior approach to the lower cervical spine. Spine (Phila Pa 1976). 2000;25(13):1603-6.

55. Netterville JL, Koriwchak MJ, Winkle M. Courey MS, Ossoff RH. Vocal fold paralysis following the anterior approach to the cervical spine. Ann Otol Rhinol Laryngol. 1996;105(2):85-91.

56. Cloward RB. Complications of anterior cervical disc operation and their treatment. Surgery. 1971;69(2):175-82

57. Yen CP, Hwang TY, Wang CJ, Howng SL. Fracture of anterior cervical plate implant - repor of two cases. Acta Neurochir (Wien). 2005;147(6):665-7; discussion 667

58. Wang JC, McDonough PW, Endow KK. Delamarter RB. Increased fusion rates with cervical plating for two-level anterior cervical discectomy and fusion. Spine (Phila Pa 1976). 2000;25(1):41-5.

59. Yoon ST, Hashimoto RE, Raich A Shaffrey $\mathrm{Cl}$, Rhee JM, Riew KD. Outcomes after laminoplasty compared with laminectomy and fusion in patients with cervical myelopathy: a systematic review. Spine (Phila Pa 1976). 2013;38(22 Suppl 1):S183-94.

60. Radcliff KE, Limthongkul W, Kepler CK, Sidhu GDS, Anderson DG, Rihn JA, et al. Cervical laminectomy width and spinal cord drift are risk factors for postoperative C5 palsy. J Spinal Disord Tech. 2014;27(2):86-92.

61. Bydon M, Macki M, Kaloostian P, Sciubba DM, Wolinsky JP, Gokaslan ZL, et al. Incidence and prognostic factors of c5 palsy: a clinical study of 1001 cases and review of the literature. Neurosurgery. 2014;74(6):595-604; discussion 5 . 